Abstract 8 Table 1 Univariable regression of patient characteristics and help with breathlessness

\begin{tabular}{|c|c|c|c|c|c|c|c|}
\hline \multicolumn{8}{|c|}{ The fan helps breathlessness } \\
\hline & & \multicolumn{2}{|c|}{$\begin{array}{c}\text { Yes (35) } \\
\text { Mean (SD), median } \\
(\mathrm{IQR}) \text { or } \underline{\mathrm{n}(\%)}\end{array}$} & \multicolumn{2}{|c|}{$\begin{array}{c}\text { No (6) } \\
\text { Mean (SD), median } \\
\text { (IQR) or } \underline{\underline{\mathrm{n}}(\%)}\end{array}$} & Odds ratio $(95 \% \mathrm{Cl})$ & p-value \\
\hline \multicolumn{2}{|l|}{ Age } & \multicolumn{2}{|c|}{$\begin{array}{r}70.7(9.5) \\
73(66-76)\end{array}$} & \multicolumn{2}{|c|}{$\begin{array}{l}66.5(9.8) \\
66(59-77)\end{array}$} & $1.05(0.96,1.14)$ & 0.324 \\
\hline \multirow[t]{2}{*}{ Sex } & Male & 20 & $83 \%$ & 4 & $17 \%$ & \multirow{2}{*}{$\begin{array}{c}\text { Reference } \\
1.50(0.24,9.30)\end{array}$} & \multirow[t]{2}{*}{0.663} \\
\hline & Female & 15 & $88 \%$ & 2 & $12 \%$ & & \\
\hline \multirow[t]{2}{*}{ Diagnosis } & COPD & 19 & $95 \%$ & 1 & $5 \%$ & \multirow{2}{*}{$\begin{array}{c}5.94(0.63,56.21) \\
\text { Reference }\end{array}$} & \multirow[t]{2}{*}{0.120} \\
\hline & Other & 16 & $76 \%$ & 5 & $24 \%$ & & \\
\hline \multirow[t]{2}{*}{ Carer } & Yes & 12 & $86 \%$ & 2 & $15 \%$ & \multirow{2}{*}{$\begin{array}{c}1.04(0.17,6.54) \\
\text { Reference }\end{array}$} & \multirow[t]{2}{*}{0.964} \\
\hline & No & 23 & $85 \%$ & 4 & $15 \%$ & & \\
\hline \multicolumn{2}{|l|}{ GSES } & \multicolumn{2}{|c|}{$31.2(4.7)$} & \multicolumn{2}{|c|}{$34.5(6.6)}$. & $0.87(0.72,1.05)$ & 0.151 \\
\hline
\end{tabular}

physical activity. There is also a signal of possible particular benefits in people with COPD which is worthy of further study.

No funding was required for this study.

\section{MEETING THE DEMANDS FOR THE FUTURE: HOW DO SPECIALIST IN-PATIENT PALLIATIVE CARE SERVICES NEED TO CHANGE TO MEET THE NEEDS OF THE POPULATION IN 2040?}

Isobel Morton. North Middlesex University Hospital, UK

10.1136/spcare-2019-mariecuriepalliativecare.9

With advances in anti-cancer treatments, for some, cancer is becoming a chronic disease. As life expectancy increases many are living longer with a higher burden of morbidity. Consequently, there is a higher demand for specialist inpatient Palliative Care services. In order to meet the requirements for the future, how does in-patient Hospice Care need to evolve?

Data regarding Hospice in-patient services was collected from Hospice Care in the UK (Hospice UK, 2017). Data regarding population forecasts was collected from the Office for National Statistics (Office for National Statistics, 2018). From this, the data was extrapolated to make forecasts about how in-patient Palliative Care will need to grow in order to satisfy the growing population.

In 2017 there were 2760 in-patient hospice beds in the UK with $71 \%$ of service users over the age of 65 . This served a population of 66.4 million of whom 18.2\% (12,084,800) were over 65 (Office for National Statistics, 2018). By 2040 the UK population is forecasted to increase by $9.1 \%$ to 72.7 million, with the over 65 population increasing to $25 \%$ $(18,172,063)$ (Office for National Statistics, 2018).

This suggests the number of in-patient Palliative beds will need to increase by $36 \%$ to 3749 by 2040 in order to meet the requirements of both a growing and aging population.
The demand for specialist in-patient Palliative Care services is set to increase exponentially, therefore the number of in-patient hospice beds will need to increase dramatically. However, this will not be sufficient in isolation, with the need for the development of other Palliative services as part of a longer-term strategy to support this increased demand.

\section{COMPLETION RATES OF DISCHARGE SUMMARIES FOR PATIENTS THAT DIE DURING THEIR ADMISSION TO HOSPITAL}

Heather Holyoak, Ningyu Chai, Farid Bazari. Kingston Hospital, UK

\subsection{6/spcare-2019-mariecuriepalliativecare.10}

All patients admitted to hospital should have a discharge summary completed, including those that have died during their admission. This ensures good continuity of care between secondary and primary care. ${ }^{1}$ We looked at the current level and practice of doctors competing discharge summaries for these patients, and the quality of information provided.

We initially looked at patients who died between November and December 2018. 114 patients died. Only 35 (31\%) patients had a discharge summary completed. A survey of junior doctors highlighted confusion about what documentation was required, they felt they are often too busy to do discharge summaries and see patients who have died as a lesser priority.

A project was conducted to highlight the importance of these summaries and to improve the quantity and quality of them being done. This included presenting our initial data at Grand Round, the Junior Doctor Forum and piloting a 'Bereavement Box' on one of the medical wards. This was used in morning board rounds to highlight summaries that needed to be done, but to also use it as an opportunity to debrief and learn from deaths. 